\title{
BOOK REVIEW: \\ Islam Politik, Teori Gerakan Sosial, dan Pencarian Model Pengkajian Islam Baru Lintas-Disiplin
}

\section{Noorhaidi Hasan}

Dosen Fakultas Syariah UIN Sunan Kalijaga, Yogyakarta

\author{
Judul Buku : Islamic Activism, A Social Movement Theory \\ Approach \\ Editor : Quintan Wiktorowicz \\ Penerbit : Bloomington dan Indianapolis, Indiana \\ University Press, 2004 \\ Halaman : $316+$ xii
}

Sejak revolusi Iran meletus tahun 1979, perhatian para sarjana terhadap gejolak Islam politik yang terjadi di berbagai belahan dunia Islam terus meningkat. Revolusi ini tak hanya mengirimkan sinyal kekuatan nyata Islam politik, tapi sekaligus mentransformasikan mimpi dan menyediakan blueprint bagi pendirian negara Islam. Memang, dunia Islam pasca-revolusi Iran menyaksikan letupan-letupan demonstrasi dan gairah menggebu-gebu menuntut reposisi peran Islam di dalam lanskap politik kenegaraan. Islam ditegaskan bukan sekadar agama, tapi juga ideologi politik. Dengan dasar ideologi tersebut negara Islam, atau setidaknya masyarakat Muslim yang taat syariah, dapat dibangun. Dibingkai dalam slogan kembali kepada apa yang dipahami sebagai model Islam yang murni-Quran, sunnah Nabi, dan praktik-praktik generasi awal Muslim — tuntutan itu mengejawantah ke dalam berbagai dimensi, dari penegasan identitas parokhial sampai usaha merekonstruksi masyarakat atas dasar prinsip-prinsip keislaman. Di dasar tuntutan itu terdapat isu penerapan syariah Islam, yang kadang 
kala mengambil bentuk aksi-aksi politik dan mobilisasi melibatkan penggunaan kekerasan.

Pendekatan-pendekatan bias Orientalis cenderung melihat Islam politik sebagai gejala keagamaan yang eksklusif. Sekalipun bersumber dari agama Protestan, istilah fundamentalisme (Islam) laku keras dalam representasi mereka tentang Islam politik. Akar gejala ini dianggap bersumber dari dalam Islam itu sendiri dan diasosiasikan dengan karakter-karakter yang khas dari ajaran-ajaran Islam. Kemungkinan adanya sumbangan kebuntuan politik, deprivasi ekonomi, stagnasi sosial, ataupun hubungan-hubungan global yang timpang dikesampingkan. Dikontraskan dengan Barat yang identik dengan modernitas, Islam muncul dalam wacana mereka sebagai peradaban yang tidak mendukung kebebasan, dinamisme, demokrasi, kesetaraan, dan rasionalitas. Anehnya, pandangan semacam ini mendapat resonansi yang cukup luas di kalangan aktivis Muslim. Mereka sibuk mendekonstruksi teks-teks suci agama dan menimpakan kesalahan kepada teks-teks itu.

Islam politik sebenarnya merupakan gejala politik-keagamaan yang tak bisa dipisahkan dari konteks power struggle. Di dalamnya terjadi perkawinan yang sempurna antara politik dan agama. Motif-motif politik yang berupaya menempatkan Islam dalam lingkar kekuasaan negara, sebagai sistem yang mengatur semua aspek kehidupan, termasuk norma hukum, sosial-budaya, sistem ekonomi, dan tata hubungan internasional, mendapatkan legitimasinya dalam bahasabahasa agama. Tonggak perkembangan Islam politik sendiri berlangsung menyusul kekalahan dunia Arab dari Israel pada Perang 1967. Kekalahan ini menyadarkan banyak Muslim akan kerapuhan rezimrezim yang berkuasa di negara-negara mereka. Janji-janji pembangunan yang didengungkan ternyata berbuah konflik, kekacauan, pengangguran, korupsi, kolusi, dan nepotisme. Sejak saat itu slogan "Islam is the solution" mulai bergema kencang di berbagai belahan dunia Islam. Dari perspektif ini, Islam politik muncul sebagai kritik atas kegagalan rezimrezim tersebut untuk memenuhi janji-janji dan harapan yang pernah mereka lambungkan.

Aura pengaruh Islam politik dan ketakutan-ketakutan terhadapnya telah mendorong para ilmuwan untuk menggelar diskusi, 
workshop, seminar, dan konferensi. Ratusan bahkan ribuan kajian telah diterbitkan, mengupas berbagai kasus dan beragam aspek Islam politik. Tetapi, analisis-analisis yang tersedia umumnya baru sebatas analisis deskriptif tentang sejarah, ideologi, struktur dan tujuan gerakangerakan yang berada dalam spektrum Islam politik. Buah dari analisisanalisis semacam ini kerap kali tak memuaskan dan cenderung mengukuhkan kecurigaan terhadap ajaran-ajaran Islam atau pengalaman-pengalaman buruk kesejarahan dunia Islam. Kalaupun pendekatan komparatif digunakan, ia terbatas pada usaha membandingkan Islam politik dengan gerakan-gerakan fundamentalisme keagamaan lainnya yang memiliki landasan ideologi dan orientasi serupa. Jarang ada analisis yang menukik tajam dengan menggunakan kerangka teoretik dan konseptual yang mendasar.

Buku ini hadir di tengah kelangkaan karya semacam itu. Ia merupakan kompilasi karya sejumlah sarjana dari berbagai belahan dunia, yang mempunyai minat dan perhatian khusus terhadap Islam politik. Mereka adalah Quintan Wiktorowicz, Mohammaed M. Hafez, Fred H. Lawson, Glenn E. Robinson, Diane Singerman, Janine A. Clark, Benjamin Smith, Jillian Schwedler, Carrie Rosefsky Wickham, Gwenn Okruhlik, M. Hakan Yavuz, dan Charles Kurzman. Berbeda dengan sarjana-sarjana Islam politik lainnya, para penulis buku ini secara konsisten berusaha untuk memperkenalkan dan menerapkan teori-teori gerakan sosial ke dalam analisis-analisis mereka tentang Islam politik. Gejala radikalisme keagamaan yang terjadi di Mesir, Palestina, Bahrain, Aljazair, Yaman, Iran, dan Turki dibedah dengan pisau tajam yang dipinjam dari teoritikus-teoritikus gerakan sosial. Pendekatan yang tergolong baru ini tak pelak membawa kesegaran dan nuansa-nuansa baru ke dalam diskusi tentang Islam politik dan sekaligus memberikan sumbangan penting bagi perkembangan teori-teori gerakan sosial itu sendiri.

\section{Teori Gerakan Sosial}

Dalam prisma kekayaan teori-teori gerakan sosial, perhatian para penulis buku ini tidak lagi berfokus pada ideologi, tapi lebih pada isu aktivisme keislaman (Islamic activism), mobilisasi yang menyertai munculnya gejala-gejala Islam politik. Teori-teori gerakan sosial memang 
mulai mendapatkan perhatian serius di tahun 1970-an ketika minat mempelajari aksi-aksi kolektif dan protes meningkat secara signifikan, sebagai respons terhadap meruaknya aksi-aksi nglurug ke jalan dari sekelompok aktor sosial yang berupaya menggugat kekuasaan elite, otoritas, ataupun lawan-lawan politik mereka—atau yang lazim disebut contentious politics. Ketidakpuasan terhadap model strukturalis-fungsional gaya lama, yang terutama concerned dengan isu grievance, mendorong sarjana-sarjana gerakan sosial kontemporer seperti Mancur Olson, Mayer Zald, dan Anthony Oberschall mengusulkan "teori mobilisasi sumber daya." Jika yang pertama menganggap aksi politik jalanan sebagai ekspresi mentalitas massa yang irrasional atau bentuk anomie dan deprivasi, teori mobilisasi sumber daya cenderung melihat gerakan sosial sebagai aksi kolektif rasional, terorganisasi dan sadar tujuan. Keberhasilannya pun sangat ditentukan oleh kecekatan aktor-aktor gerakan untuk mengorganisasi kekecewaan, meminimalisasi resiko yang mungkin timbul, sekaligus memanfaatkan jaringan-jaringan solidaritas sosial yang ada dan membagi insentif untuk mencapai konsensus bersama.

Teori gerakan sosial menawarkan jalan tengah antara mazhab strukturalis yang terlalu berfokus pada sistem (negara atau relasi internasional) dan mazhab pilihan rasional yang melebihkan peran individual. Berbeda dengan keduanya, teori gerakan sosial mengambil kelompok sebagai unit analisis. Sementara mengakui individu yang terlibat aksi kolektif memiliki pilihan bebas, teori gerakan sosial menjelaskan bahwa pilihan itu tidak terjadi di dalam ruang hampa, di luar konteks, relasi, dan jaringan yang berubah. Jadi, pilihan individu tidak bisa dipahami di luar konteks sosial kelompok. Oleh karena itu, teori gerakan sosial mengakui pentingnya perubahan struktural dalam menciptakan kondisi yang memungkinkan terjadinya aksi-aksi kolektif. Aktor-aktor gerakan sosial bertindak dalam parameter-parameter perubahan semacam itu, meski tidak semua perubahan struktural membawa hasil yang sama. Dinamika bagaimana kelompok mengambil keuntungan dari sebuah perubahan sangatlah penting diperhatikan untuk memahami munculnya gerakan sosial. Teori gerakan sosial memang memberikan tekanan khusus pada isu komunalitas gerakan yang berakar pada proses; bagaimana sebuah gerakan muncul dan 
kondisi apa yang memungkinkan suatu "kekecewaan" bermetamorfosis menjadi mobilisasi.

Terdapat tiga konsep kunci dalam teori gerakan sosial yang biasanya memainkan peran yang sangat penting dalam menentukan keberhasilan aksi-aksi kolektif. Ketiga konsep itu meliputi (1) struktur kesempatan politik (political opportunity structure), (2) struktur mobilisasi (mobilizing structures), dan (3) pembingkaian aksi (framing). Konsep struktur kesempatan politik menjelaskan bahwa munculnya gerakan sosial seringkali dipicu oleh perubahan-perubahan signifikan yang terjadi dalam struktur politik dan karenanya, meredupnya gerakan itu juga biasanya berhubungan dengan pergeseran-pergeseran yang terjadi di dalamnya. Dengan kata lain, struktur kesempatan politik berdampak mempercepat terjadinya ataupun mengakhiri aksi kolektif. Namun, struktur kesempatan politik saja tidak cukup mendorong terjadinya aksi kolektif. Ia harus ditopang oleh struktur mobilisasi yang biasanya berakar dalam jaringan-jaringan sosial yang sudah terbangun sebelumnya. Melalui jaringan itu massa dan simpatisan direkrut dan dimobilisasi. Keberadaan jaringan rekruitmen memang menjadi penentu dalam proses pelibatan individu, karena mobilisasi tidak berlangsung dalam ruang hampa. Untuk memobilisasi massa itulah aktor-aktor gerakan sosial perlu membingkai aksi-aksi yang mereka rencanakan dengan slogan-slogan dan bahasa yang mudah dipahami dan sekaligus dapat menggerakkan sentimen mereka. Di sinilah arti penting framing sebagai seni mengkomunikasikan pesan untuk menggerakkan audien dan memompa dukungan serta partisipasi. Ideologi, sebagai sistem kepercayaan, ide, nilai, dan makna, biasanya bekerja untuk mendukung efektivitas framing ini.

Teori gerakan sosial memberikan keuntungan bagi upaya memahami berbagai gejala Islam politik secara lintas-disiplin. Ia meneropong tidak saja dinamika kesejarahan, tapi juga proses dan organisasi aktivisme yang mengusung bendera Islam. Ia sekaligus memberikan pemahaman bagaimana dinamika, proses dan organisasi aktivisme keislaman itu dapat dipahami sebagai unsur penentu terjadinya aksi kolektif, yang bekerja melampaui keunikan Islam sebagai sistem makna, identitas, dan basis aksi kolektif. Meski warna ideologis membedakan aktivisme keislaman dalam beberapa hal dari aksi-aksi 
kolektif lainnya yang berorientasi sekular, ia bukanlah sui generis, terutama jika dipertimbangkan dinamika, proses, dan organisasi aktivisme itu. Sama halnya dengan aksi-aksi kolektif lainnya, ia rasional dan muncul karena persentuhannya dengan dinamika politik tertentu, melalui proses mobilisasi yang melibatkan jaringan-jaringan rekruitmen yang rumit dan dipoles dengan sentuhan-sentuhan ideologi melalui framing yang tepat. Dengan meletakkan aktivisme keislaman dalam sudut pandang semacam itu, buku ini memberi sentuhan teoretik yang sangat mendasar dan membebaskan diri dari wacana kesarjanaan "bias lapis langit ke tujuh," yang selalu mencari jawaban persoalan kini yang berhubungan dengan umat Islam dari teks-teks suci agama atau sejarah tujuh abad silam.

\section{Marjinalisasi dan Kekerasan}

Buku ini terbagi ke dalam tiga bagian. Bagian pertama yang terdiri dari empat bab, yang masing-masing ditulis Mohammed M. Hafez, Quintan Wiktorowicz, Fred H. Lawson, dan Glenn E. Robinson, mendiskusikan dinamika kekerasan dalam aksi-aksi kolektif di Aljazair, Mesir, Bahrain, dan Palestina secara berturut-turut. Keempat tulisan ini dengan jernih berhasil menunjukkan adanya hubungan yang koheren antara repertoire kekerasan (atas nama agama) dengan dinamika struktur kesempatan politik. Bagian ini sangat menarik dan penting untuk mengisi keingin-tahuan masyarakat internasional dan debat tentang terorisme "Islam" pasca-tragedi 11 September dan pencanangan kampanye global melawan terorisme yang bias kepentingan. Dalam debat yang melibatkan pengamat, analis, ilmuwan, pengambil kebijakan, dan masyarakat luas itu, Islam menjadi begitu identik dengan terorisme. Ajarannya tentang jihad dianggap berada di balik aksi serangan puluhan pemuda Arab berjenggot dalam tragedi itu. Aksi mereka diklaim murni sebagai ungkapan fanatisme keagamaan dan didorong semangat mencari kesyahidan. Jihad gagal dipahami dalam dimensinya yang luas sebagai simbol dan bahasa protes yang dapat dieksploitasi oleh segmen masyarakat yang termarjinalkan untuk menawar posisi mereka di ruang publik.

Keempat bab ini menunjukkan bagaimana aksi-aksi kekerasan Kelompok Islam Bersenjata (GIA) di Aljazair, Jama'ah Islamiyah di 
Mesir, Syi'ah di Bahrain, dan Hamas di Palestina sepanjang tahun 1990an bergerak parallel dengan dinamika politik di masing-masing negara, dan ini mencerminkan pilihan rasional dan dimensi-dimensi strategis dan taktis mereka. Pada keempat kasus dalam setting yang berbeda ini penggunaan kekerasan merupakan respons taktis terhadap perubahan struktur kesempatan politik, yang dimensinya meliputi aksesibilitas sistem (system accessibility) dan pola represi negara (state repression). Sebagaimana ditunjukkan Hafez dalam kasus GIA di Aljazair, aksiaksi kekerasan kelompok ini meningkat ketika aksesnya terhadap sistem kekuasaan negara sama sekali tertutup, yang diikuti dengan represi brutal dan tanpa ampun yang mendorong para anggota untuk mengkonsolidasikan diri di bawah tanah. Kondisi semacam ini biasanya membuat kerangka-kerangka aksi anti-sistem (anti-system frames) bergema kencang memotivasi aksi kolektif. Represi memang dalam banyak hal menciptakan rasa ketidakadilan, melegitimasi seruan penggunaan kekerasan, dan memaksa organisasi-organisasi radikal tiarap dan semakin terpisah dari masyarakat luas.

Hal yang hampir sama terjadi dalam kasus Jama'ah Islamiyah di Mesir. Kelompok ini meningkatkan aksi-aksi kekerasannya ketika ditendang keluar dari lingkar sistem politik kelembagaan negara oleh rezim pemerintah Mesir dan dihadapkan dengan represi brutal yang bersifat reaktif dan indiscriminate. Padahal sebelumnya, ia diberikan kesempatan oleh rezim itu-dalam rangka menahan pengaruh kekuatankekuatan kiri-untuk menikmati ruang organisasional tertentu yang memungkinkannya mengembangkan layanan-layanan sosial, mengambil alih masjid-masjid, dan membangun hubungan dengan komunitaskomunitas lokal. Kasus perlawanan kaum Syi'ah di Bahrain terhadap rezim al-Khalifa yang didominasi Sunni tidak jauh berbeda dengan dua kasus di atas. Respons yang berlebihan dari rezim al-Khalifa yang membatasi taktik-taktik moderat kaum Syi'ah ternyata cenderung meradikalisasi pemberontakan dan pemakaian bahasa kekerasan. Dimensi yang sama terdapat dalam kasus perlawanan Hamas terhadap represi Israel di Palestina. 


\section{Jaringan Sosial Informal}

Gerakan sosial bukan sekadar wacana, tapi aksi yang melibatkan banyak orang dan pengorganisasian yang rumit. Berbeda dengan gerakan-gerakan sosial di Barat yang biasanya melakukan mobilisasi melalui organisasi-organisasi gerakan sosial (Social Movement Organizations), aktivisme keislaman lebih sering memanfaatkan jaringanjaringan sosial informal yang terbangun melalui hubungan-hubungan personal. Bahkan organisasi-organisasi Islam formal, seperti Ikhwanul Muslimin, terdiri atas jaringan-jaringan dinamis yang berada di luar parameter organisasi formal dan mengandalkan koneksi-koneksi persahabatan, kekeluargaan, dan kolegial. Melalui ḥalāqah-ḥalāqah dan dawrah yang digelar di beranda-beranda masjid, forum telaah tafsir di musalla, pengajian di rumah-rumah, atau pamflet, buku, dan media cetak Islami yang dikemas menarik, jaringan-jaringan itu berkembangbiak dan suatu saat siap digerakkan melalui seni mobilisasi tertentu.

Bagian kedua buku ini, yang juga terdiri dari empat bab, masingmasing ditulis oleh Diane Singerman, Janine A. Clark, Benjamin Smith, dan Jillian Schwedler, mengulas dinamika aktivisme keislaman dalam memanfaatkan jaringan-jaringan sosial informal bagi keberhasilan aksiaksi kolektifnya. Bagi Singerman yang mengkaji kasus Kairo, jaringanjaringan sosial informal memiliki keabsahan secara kultural, karena menyatu dengan masyarakat, dan jaringan-jaringan itu dapat berfungsi sebagai sumber daya gerakan dan kolam rekruitmen untuk aksi-aksi kolektif. Melalui jaringan semacam itu identitas kolektif dan solidaritas dibangun, memungkinkan mobilisasi berlangsung efektif dan free-riding problem-ketika banyak orang berpikir untuk tidak terlibat bila menyadari resiko yang mungkin dihadapi dan menyerahkan nasib mereka kepada orang lain—teratasi. Dengan nada yang sama, Clark dalam studinya tentang Partai al-Iṣlāh di Yaman menunjukkan bagaimana aktivis gerakan sosial menggunakan nadwah (kelompok studi al-Quran) untuk mereproduksi pesan-pesan dan mendukung agendaagenda serta aktivitas mereka. Saluran ini menfasilitasi keterlibatan banyak segmen masyarakat Yaman, termasuk kaum perempuannya, dalam mendukung sepak terjang Partai al-Iṣlāh.

Jenis jaringan yang sedikit berbeda diungkap oleh Smith dalam kasus bazār di Iran. Ia menggarisbawahi fakta bahwa jaringan tidak 
selalu terbangun melalui hubungan-hubungan personal antar individu yang berpikiran sama, tapi dapat melalui koneksi dan aliansi taktis dari beberapa kelompok yang berbeda. Sekalipun anggota-anggota komunitas bazāry (dagang) mendukung ideologi Khomeini, mereka ternyata bergerak di bawah payung yang berbeda-beda dan untuk kepentingan yang berbeda-beda pula. Hanya saja, mereka mempunyai misi yang sama untuk meruntuhkan rezim Pahlevi yang korup. Aliansi semacam ini biasanya temporal dan dapat berubah dengan cepat seiring bergesernya kepentingan kelompok-kelompok pendukung. Hal serupa terjadi di Yaman, sebagaimana ditunjukkan Schwedler, ketika rezim berusaha menggunakan Partai al-Iṣlāh sebagai sekutu strategis untuk menghancurkan Partai Sosialis Yaman.

\section{Budaya dan Framing}

Bagian terakhir buku ini yang terdiri dari tiga bab, masing-masing ditulis Carrie Wickham, Gwenn Okruhlik, dan Hakan Yavuz, mendiskusikan bagaimana aktivisme keislaman berhasil memotivasi, mengilhami, dan menuntut loyalitas para pengikut melalui seni framing. Dengan mengeksploitasi simbol, bahasa, dan sejarah budaya masyarakat Muslim, sentimen massa digerakkan dalam pesan-pesan yang dikemas efektif tentang marjinalisasi politik, deprivasi ekonomi, dan ketidakberdayaan rezim masing-masing menghadapi kekuatankekuatan asing dan arus globalisasi. Pesan-pesan itu tentu saja dipoles dengan ayat-ayat suci dan hadis-hadis Nabi sehingga beresonansi luas di berbagai segmen masyarakat.

Menyorot kasus Mesir, Wickham menunjukkan keberhasilan aktivisme keislaman untuk menjangkau lapisan kelas menengah bawah melalui kecermatannya membingkai gerakan. Pesan "kewajiban moral" berpartisipasi memperbaiki nasib masyarakat berdengung cukup luas dan mendorong para lulusan universitas dari kalangan kelas menengah bawah untuk bergabung ke dalam gerakan keislaman. Okruhlik menelaah kasus Saudi Arabia untuk menjelaskan bagaimana kaum Islamis di negeri ini menggeser pemahaman-pemahaman budaya tentang bentuk-bentuk aktivisme yang diperkenankan. Di dalam masyarakat konservatif kerajaan Saudi, satu-satunya frame yang efektif adalah yang menggunakan Islam sebagai bahasa dan medium aktivitas- 
aktivitas oposisional. Perhatiannya tertuju pada nasiby, memorandum nasihat, yang dikirim sekelompok aktivis kepada rezim. Dipoles dengan teks-teks kitab suci, nasihat ini berhasil menembus taboo yang selama ini menggelayuti kebekuan masyarakat dan sekaligus memicu debat serta kritik terhadap rezim. Yavuz dalam bab terakhir mengenai Turki mengkaji kontestasi framing dalam konteks liberalisasi kebijakankebijakan ekonomi yang dijalankan pemerintah.

\section{Penutup}

Memperhatikan wawasan-wawasan dan kedalaman analisis babbab yang dihadirkannya, buku ini jelaslah penting dibaca dan hadir menjadi semacam methodological breakthrough dalam kajian-kajian tentang Islam dan masyarakat Muslim. Sebagaimana disinggung Kurzman dalam kesimpulan, ia meretas kebekuan kajian-kajian Islam konvensional yang berakar dalam tradisi Orientalisme, dengan menghadirkan pendekatan yang menekankan otentisitas dan rasionalitas indigeneous subject voices. Ia sekaligus menyajikan contoh pemanfaatan ilmu-ilmu sosial secara maksimal dalam studi-studi keislaman. Meski demikian, buku ini masih terbatas jangkauan analisis empirisnya pada Timur Tengah. Banyak kawasan dunia Islam lainnya yang belum disentuh. Sebagai karya rintisan, tentu saja hal itu bisa dipahami, dan mestinya dapat mendorong ilmuwan-ilmuwan lain untuk melakukan kajian serupa di kawasankawasan yang berbeda. 